\title{
CONSTRUÇÃO DE SISTEMA QUE PERMITE A ANCORAGEM DE PROTEÍNA RECOMBINANTE À SUPERFÍCIE CELULAR DE LEVEDURA
}

\author{
JESSICA PAOLA FUENTES RIVERA NAVARRO
}

Disertação apresentada ao Programa de PósGraduação Interunidades em Biotecnologia USP/Instituto Butantan/IB/ICB/IPT, para obtenção do Título de Mestre em Biotecnologia.

Área de concentração: Biotecnologia

Orientador(a): Profa. Dra. Elisabete José Vicente

São Paulo 2008 


\section{RESUMO}

Fuentes Rivera JPN. Construção de sistema que permite a ancoragem de proteína recombinante à superfície celular de levedura [Dissertação]. São Paulo: Instituto de Ciências Biomédicas da Universidade de São Paulo; 2008.

Sistemas do tipo "cell surface display" vêm sendo desenvolvidos para expressão de proteínas heterólogas ancoradas à superfície celular de microrganismos. Várias aplicações foram reportadas destes sistemas, incluindo o emprego como biocatalizador celular, desenvolvimento de vacinas e biosorventes celulares.

Neste trabalho foi desenvolvido um sistema que permite ancoragem da proteína glicoamilase de Aspergillus awamori à superfície da parede celular da levedura Saccharomyces cerevisiae. O gene codificador da glicoamilase com sua seqüência sinal foi fusionado ao fragmento do gene codificador da região Cterminal da proteína Flo1p (Flo428), que foi utilizada como âncora (fragmento $\mathrm{CG}^{\star} \mathrm{FC}$ ). As células de levedura foram transformadas com o fragmento híbrido $\mathrm{CG}^{\star} \mathrm{FC}$ e os transformantes foram capazes de degradar amido e liberar glicose. A atividade da glicoamilase não foi detectada no meio de cultura, porém está presente no sedimento celular. Estes resultados demonstram que a glicoamilase foi ancorada à parede celular da nova linhagem recombinante de levedura.

Palavras-chave: Saccharomyces cerevisiae. Âncora Flo1p. Glicoamilase. Superfície celular. Sistema de ancoragem de proteína. Biotecnologia. 


\begin{abstract}
Fuentes Rivera JPN. Construction of a system that allows anchoring of recombinant protein to the cell surface of yeast [Master thesis]. São Paulo: Instituto de Ciências Biomédicas da Universidade de São Paulo; 2008.

Cell surface display systems have being developed for expression of heterologous proteins anchored to the cell surface of microorganisms. Several applications of these systems have been reported, including employment as whole-cell biocatalysts, development of vaccines and cellular biosorvents.

In this work it was developed a system that allows the anchoring of the Aspergillus awamori glucoamylase protein to the cell wall surface of the yeast Saccharomyces cerevisiae. The gene encoding glucoamylase with its secretion signal was fused to the gene fragment encoding the C-terminal region of Flo1 protein, used as an anchor ( $\mathrm{CG}^{*} \mathrm{FC}$ fragment). Yeast cells were transformed with hybrid $\mathrm{CG}^{\star} \mathrm{FC}$ fragment and transformants were able to degrade starch and release glucose. Glucoamylase activity was not detected in the culture medium, but only in sedimented cells. These results demonstrate that glucoamylase was anchored to the cell wall of the new recombinant strain yeast.
\end{abstract}

Key words: Saccharomyces cerevisiae. Anchor Flo1p. Glucoamylase. Cell wall. Anchoring protein system. Biotechnology. 


\section{INTRODUÇÃO}

\subsection{Leveduras}

As leveduras fazem parte de um grupo de microrganismos eucariontes inferiores, unicelulares amplamente distribuídas na natureza. Elas têm sido utilizadas pelo homem há milhares de anos, em processos de fermentação alcoólica e preparo de pães, causando um grande impacto na produção de alimentos e influenciando no desenvolvimento sócio-econômico da humanidade. Embora as leveduras sempre tenham tido importante papel nesses processos, o conhecimento da participação de organismos vivos na fermentação foi demonstrado em 1876 por Louis Pasteur. Posteriormente, Hansen isolou leveduras de processos de fermentação e propagou a cultura pura. Esse fato propiciou o grande desenvolvimento dos processos fermentativos e como conseqüência, muitas alterações tem sido feitas nesses processos (Hammond,1993).

Saccharomyces cerevisiae é uma das espécies de levedura mas estudadas e empregadas em processos industriais como produção de alimentos como pão ou cerveja; extrato de levedura; como suplemento alimentar para ração animal, produção de aroma e sabor em alimentos; bebidas como vinho, sake, bebidas destiladas em geral; glicerol e, na produção de álcool combustível. Devido ao emprego da tecnologia do DNA recombinante tanto a levedura S. cerevisiae como leveduras relacionadas, ganharam grande implulso na produção de varias proteínas heterólogas (Walker,1998). Consequentemente S. cerevisiae é reconhecida pelo FDA americano como um organismo seguro, "GRAS" ("Generally Recognized As Safe"), para ser empregada como alimento e produção de fármacos, não oferecendo riscos de contaminação por substâncias tóxicas ou alergênicas normalmente presentes em bactérias (Romanos et al., 1992).

S. cerevisiae é um fungo unicelular ascomiceto, que pode alternar seu ciclo de vida com fase sexuada e fase assexuada ou vegetativa, apresentando células na forma haplóide (n) ou diplóide (2n) (Figura 1). O tamanho da célula 
haplóide e diplóide varia com a fase de crescimento e de linhagem para linhagem. Tipicamente, células diplóides têm forma elipsoidal e medem aproximadamente $5 \times 6 \mu \mathrm{m}$ enquanto que as células haplóides tem forma esférica e medem aproximadamente $4 \mu \mathrm{m}$ de diâmetro (Sherman, 1979). As células haplóides podem ser de dois tipos de acasalamento MATa e MATa. Durante a fase assexuada as células diplóides $(2 n)$ e haplóides ( $n$ ) podem dividir-se por mitose, replicando se por um processo denominado brotamento, pelo qual a célula parental produz um broto que cresce durante o ciclo celular até finalmente separar-se da célula original. $\mathrm{Na}$ fase sexuada, duas células haplóides ( $\mathrm{n}$ ) de diferentes tipos de acasalamento podem se cruzar, originando uma célula diplóide (2n) MATa/MATa (Sprague, 1995). As células diplóides podem multiplicar-se indefinidamente por mitose, porém em condições adversas, como falta de nutrientes, as células podem sofrer meiose formando 4 esporos haplóides ( $\mathrm{n})$, denominadas ascósporos, as quais permanecem contidas no interior da célula parental, em uma estrutura conhecida como asco. Após a clivagem enzimática da parede celular do asco, os esporos haplóides podem ser individualmente isolados e analisados, permitindo um estudo genético detalhado.

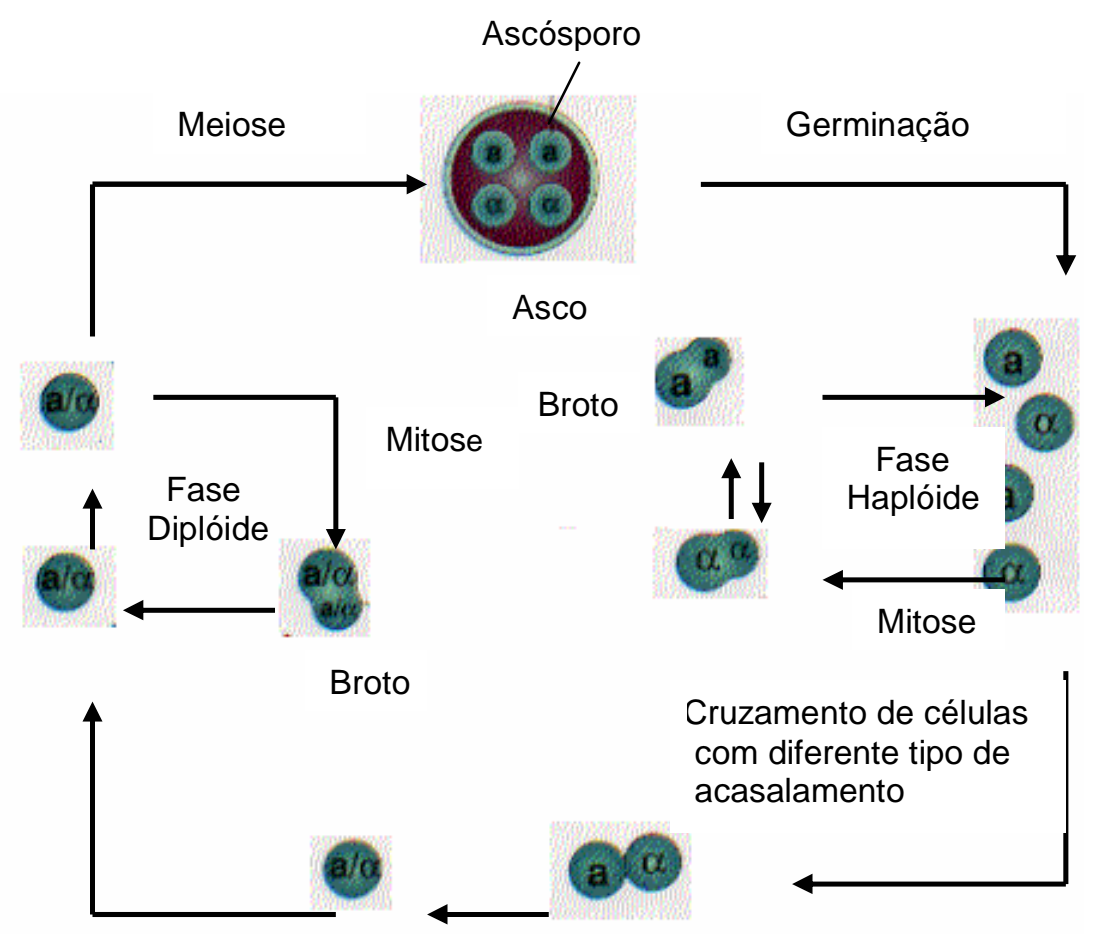

Figura 1. Ciclo de vida de Saccharomyces cerevisiae 
Os conhecimentos sobre a genética, fisiologia e a biologia molecular de S. cerevisiae estão hoje mais avançados do que para qualquer outro eucarioto, podendo as células ser manipuladas quase tão facilmente quanto a bactéria Escherichia coli, além disso foi o primeiro eucarioto a ter seu genoma completamente seqüenciado (Goffeau et al., 1996).

\subsection{Expressão de genes heterólogos em leveduras}

Por serem organismos unicelulares, as leveduras apresentam as mesmas facilidades de manipulação e crescimento que as bactérias, porem com uma série de vantagens adicionais, no que se refere à produção de proteínas heterólogas de origem eucarionte, como: ambiente intracelular favorável à correta formação das proteínas de eucariotos (Valenzuela et al., 1982); mecanismos de transcrição, tradução e processamento pós-transcricional, são semelhantes àqueles observados em células de eucariontes superiores (Kingsman e Kingsman, 1987); capacidade de processar modificações póstraducionais para produção de proteínas heterólogas como: glicosilação, acilação e fosforilação (Kukuruzinska et al., 1987; Miyamoto et al., 1985; Towler et al.; 1988) que contribuem para a manutenção da integridade estrutural, solubilidade, atividade biológica e localização celular das proteínas, bem como a capacidade de secreção eficiente, o que facilita a separação dos produtos recombinantes a partir do meio de cultura.

A introdução de genes exógenos em células de $S$. cerevisiae é realizada através de métodos de transformação genética. Ao final dos anos 70, Hinnen et al. (1978) e Beggs (1978) demonstraram ser possível a transformação genética da levedura $S$. cerevisiae.

A partir da primeira publicação mostrando à expressão de um gene heterólogo em $S$. cerevisiae (Hitzeman et al.,1981) esse microrganismo vem sendo largamente empregado como sistema hospedeiro (Romanos et al., 1992). A extensão e diversidade de produtos expressos nesse microrganismo é significativa, variando desde simples enzimas a hormônios, fatores de crescimento, proteínas sanguíneas ou estruturas complexas como anticorpos 
(Hadfield et al., 1993). Nas industrias de fermentação, tais como cervejeira, de panificação ou produção de bebidas destiladas, o esforço tem sido focalizado no sentido de introduzir genes heterólogos codificadores de proteínas com atividades enzimáticas que possibilitem o melhoramento da eficiência e/ou capacidade do processo.

Um sistema de transformação genética depende de alguns fatores como a introdução de uma molécula de DNA exógeno, a manutenção desse DNA no microrganismo hospedeiro e a seleção desse evento (Wery et al., 1999)

O primeiro método de transformação genética de leveduras empregou esferoblastos (células de levedura sem parede celular) que foram incubados na presença de DNA exógeno (Hinnen et al.,1978). Posteriormente, foi desenvolvido outro método de transformação, usando células intactas de levedura tratadas com sais de lítio que foram posteriormente incubadas em presença de DNA (Ito et al., 1983). Foram descritos também outros métodos de transformação genética utilizando pérolas de vidro (Costanza e Fox, 1988) e biolistic (Johnston et al.,1988). Atualmente pode-se usar o método de eletroporação, muito mais rápido e simples para a transformação genética de leveduras. Este método consiste em abrir poros na célula através da ação da corrente elétrica, possibilitando assim a entrada do DNA exógeno com maior eficiência (Meilhoc et al., 1990).

As principais etapas na expressão de genes heterólogos em células de levedura são descritas na Tabela 1. 
Tabela 1 - Principais etapas na expressão de genes heterólogos em células de levedura (Walker, 1998).

\begin{tabular}{|c|c|}
\hline Etapa & Descrição \\
\hline $\begin{array}{l}\text { Isolamento } \\
\text { do gene }\end{array}$ & $\begin{array}{l}\text { O gene estrutural codificador da proteína de interesse é isolado } \\
\text { de fragmentos de restrição de DNA ou fragmentos de DNA } \\
\text { amplificado por PCR do organismo doador. }\end{array}$ \\
\hline Clonagem & $\begin{array}{l}\text { O gene heterólogo é manipulado in vitro e inserido num vetor de } \\
\text { expressão o qual contem um cassete de expressão formado por: } \\
\text { seqüência promotora - gene estrutural - seqüência terminadora. }\end{array}$ \\
\hline Transformação & $\begin{array}{l}\text { O vetor é introduzido nas células de levedura, utilizando o método de } \\
\text { acetato de lítio (ITO et al., 1983) ou eletroporação (Becker e } \\
\text { Guarante, 1991) ou esferoblastos, o qual foi o primeiro método } \\
\text { descrito na literatura (Beggs, 1978; Hinnen et al., 1978). }\end{array}$ \\
\hline Seleção & $\begin{array}{l}\text { As marcas genéticas seletivas presentes nos vetores são utilizadas } \\
\text { para identificar os transformantes. }\end{array}$ \\
\hline Expressão & $\begin{array}{l}\text { A expressão heteróloga de genes envolve: transcrição empregando } \\
\text { um promotor de levedura fusionado a montante do gene estrutural, o } \\
\text { promotor contem seqüências AUS e TATA, promovendo a regulação } \\
\text { da expressão gênica; terminação da transcrição utilizando } \\
\text { seqüências terminadoras fusionadas a jusante do gene estrutural, } \\
\text { para a terminação eficiente do mRNA transcrito; transporte do mRNA } \\
\text { do núcleo para o citoplasma; início da tradução e alongamento da } \\
\text { cadeia polipeptídica. }\end{array}$ \\
\hline Modificações & $\begin{array}{l}\text { As proteínas heterólogas podem ser sujeitas as modificações pós- } \\
\text { traducionais (exemplo: glicosilação, acetilação, etc.). }\end{array}$ \\
\hline $\begin{array}{l}\text { Secreção e } \\
\text { Excreção }\end{array}$ & $\begin{array}{l}\text { O peptídeo sinal direciona a proteína à membrana do reticulo } \\
\text { endoplasmático onde ocorre a traslocação para o lúmen. O peptídeo } \\
\text { sinal é removido por uma peptidase e a proteína é transportada } \\
\text { através da via secretora e liberada para o espaço periplasmático } \\
\text { (secreção) e ou, subsequentemente, para o meio extracelular } \\
\text { (excreção). }\end{array}$ \\
\hline
\end{tabular}


Para a inserção de genes heterólogos na célula da $S$. cerevisiae foram desenvolvidos diferentes vetores de transformação genética. Geralmente são empregados vetores bifuncionais, os quais contem uma origem de replicação para E. coli e outra para S. cerevisiae; marcador de seleção para bactérias, como genes que conferem resistência a antibióticos, tornando as células bacterianas resistentes ao antibiótico; marcador de seleção para levedura como: leucina (leu2), uracila (ura3), triptofano (trp1) e histidina (his3), que complementam uma mutação auxotrófica em linhagens de $S$. cerevisiae, permitindo a seleção das células de levedura transformadas por complementação gênica em meio carente do aminoácido em questão. Também é possível selecionar transformantes de leveduras que receberam vetores de transformação contendo genes que conferem resistência a antibióticos de $4^{\underline{0}}$ geração como higromicina ou geneticina (G418) (Romanos et al., 1992; Camargo, 2000; Kim et al., 2001; Rubio, 2001; Guerra, 2002; Sambrook e Russel, 2001).

Em um vetor bifuncional de interesse biotecnológico, é indispensável que este contenha um cassette de expressão, formado por uma seqüência promotora, o gene estrutural e a seqüência terminadora de transcrição, de forma que possa ocorrer perfeitamente a transcrição e a tradução do gene de interesse, resultando na produção da proteína desejada. Estão disponíveis vários promotores de levedura bem conhecidos, que foram seqüenciados e clonados em diversos plasmídios, facilitando a construção de novos vetores de expressão. Os promotores de levedura são em geral altamente complexos, contendo múltiplas seqüências de ativação a montante (UASs), sítios de regulação negativa e múltiplos elementos TATA associados a diferentes sítios iniciadores.

Promotores de gene glicolíticos são muito utilizados para expressão de genes heterólogos em leveduras (Shuster, 1989). Estes promotores constitutivos exibem uma forte atividade, o que faz com que as proteínas heterólogas expressas sob seu controle, sejam produzidas em grandes quantidades pelas células. Trabalhos utilizando expressão heteróloga são 
feitos, em sua maioria, com promotores que proporcionam alta produção de proteínas, e que, acredita-se, apresentam expressão constitutiva durante o crescimento celular. Os promotores PGK1 e $A D H 1$ são os principais promotores glicolíticos utilizados no estudo de expressão de genes (Hauff et al., 2000).

Os vetores empregados podem ser divididos em duas classes: aqueles que se integram no cromossomo via recombinação homóloga (Ylp- "Yeast Integrative plasmids") e aqueles que tem replicação autônoma, conferida por: plasmídio $2 \mu$ natural de levedura (YEp- "Yeast Epissomal plasmids") ou por seqüências de replicação autônoma ( $\underline{\mathrm{ARS}})$ que funcionam como origem de replicação (YRp- "Yeast replicative plasmids"). Geralmente, os vetores integrativos são herdados com grande estabilidade, enquanto que os vetores com replicação autônoma tendem a ser instáveis.

Os vetores YRp podem ser estabilizados pela adição de seqüências centroméricas de levedura (CEN), porém o número de cópias é reduzido a uma ou duas por célula (YCp- "Yeast centromeric plasmid"). Os vetores denominados YAC ("Yeast artificial chromosomes") baseiam-se em vetores com regiões ARS/CEN contendo, adicionalmente, dois telômeros. Estes vetores apresentam estabilidade e propriedades semelhantes a de um cromossomo natural, desde que, seu tamanho seja superior a 55kb (Old e Primrose, 1995).

A utilização de qualquer um dos plasmídios descritos, impõe todavia, que se empregue uma cepa hospedeira com marcador de auxotrofia adequado para que se possa selecionar os transformantes em meio mínimo por complementação gênica. Entretanto, leveduras de interesse industrial como cepas selecionadas para a produção de etanol, vinho, cerveja e ainda cepas empregadas na panificação, são cepas selvagens que não apresentam marcador de auxotrofia. Portanto novos vetores, que dispensam a utilização de marcas auxotróficas para seleção de células recombinantes despertaram grande interesse, uma vez que podiam ser empregados na transformação genética de linhagens de levedura prototróficas industriais e também na transformação genética de linhagens de levedura auxotróficas de laboratório 
Em 1983 Rothstein demonstrou a possibilidade de provocar disrupção de um gene através da recombinação entre as seqüências homólogas de DNA do genoma e as presentes no fragmento de DNA linear. Para causar mutação através deste processo, deve-se empregar na transformação de levedura um fragmento de DNA que contenha o gene de seleção, ladeado por seqüências do gene alvo. Uma vez que na levedura ocorre preferencialmente recombinação homóloga, este fragmento deve conter, de cada lado, ao menos 250 pares de bases do gene alvo para que a recombinação seja eficiente (Ausubel et al.,1989). Terminações de DNA livre são altamente recombinogênicas, promovendo recombinação com as seqüências homólogas no genoma da levedura, resultando em troca do gene selvagem pela cópia ocorrendo a disrupção gênica (Rothstein, 1983) (Figura 2).

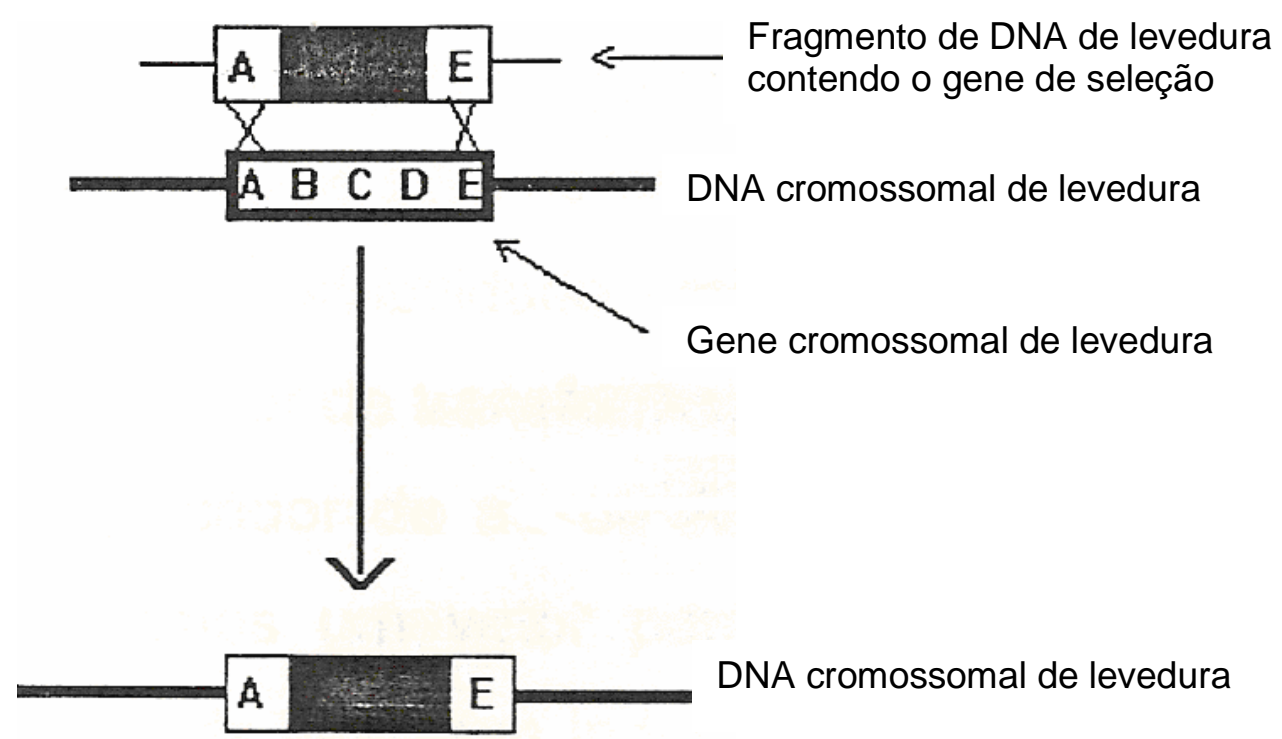

Figura 2. Disrupção Gênica (Rothstein, 1983). 


\subsection{Sistema de transformação CAN1}

O gene CAN1 presente no cromossomo $\mathrm{V}$ de $S$. cerevisiae, codifica a proteína responsável pela permease da arginina (Can1p) (Opekarová et al., 1998).

A permeabilidade celular controlada pelo gene CAN1 é mediada por uma proteína associada à membrana celular. Durante o crescimento em meio mínimo, a permease da arginina é o único sistema de transporte deste aminoácido para o interior da célula (Broach et al., 1979; Whelan et al., 1979). Linhagens de levedura, com o gene CAN1 funcional, são sensíveis a um aminoácido básico análogo da arginina, isolado da leguminosa Canavalia ensiformis na forma de L-canavanina (The Merk.Index, 1976). L- canavanina é um potente inibidor de crescimento de muitos organismos, inclusive S. cerevisiae e outras leveduras. Quando a célula produz a permease da arginina torna-se apta a incorporar arginina e, por conseqüência, L-canavanina se esta estiver presente no meio, o que inibirá o crescimento celular. Isto ocorre enquanto o gene CAN1 estiver sendo expresso. Porém, se a célula sofrer alguma mutação no gene $C A N 1$, a mutante can1, deixará de produzir a permease da arginina não permitindo a entrada de L-canavanina e passará a ser resistente à droga apresentando crescimento no meio, após alguns dias de incubação.

Num trabalho anteriormente desenvolvido em nosso Laboratório, foi estabelecido o sistema de transformação genética CGC (Camargo e Vicente, 1994; Camargo e Vicente, 2000), o qual é composto pelo c-DNA da glicoamilase de Aspergillus awamori, sob o comando do promotor e terminador de transcrição do gene da fosfoglicerato quinase $(P G K)$ de $S$. cerevisiae, flanqueado por fragmentos do gene CAN1 de $S$. cerevisiae: Fragmento CGC. Este sistema provoca a disrupção gênica através de sua integração na região homóloga ao gene CAN1 de $S$. cerevisiae, permitindo a seleção dos clones transformantes que tornam-se resistentes à L-canavanina, introduzindo assim uma informação genética adicional, que se mantém estável como parte do genoma da célula de levedura. 
Portanto, neste projeto foi empregado o sistema de transformação CAN1 composto pelo cassete de expressão e ancoragem da glicoamilase, flanqueado pelos fragmentos do gene CAN1 de $S$. cerevisiae: "CAN1 - pPGK - cDNA glicoamilase - Flo428 - tPGK - CAN1" (Fragmento $\mathrm{CG}^{\star} \mathrm{FC}$ ), introduzindo a informação desejada no genoma da célula de levedura.

A.
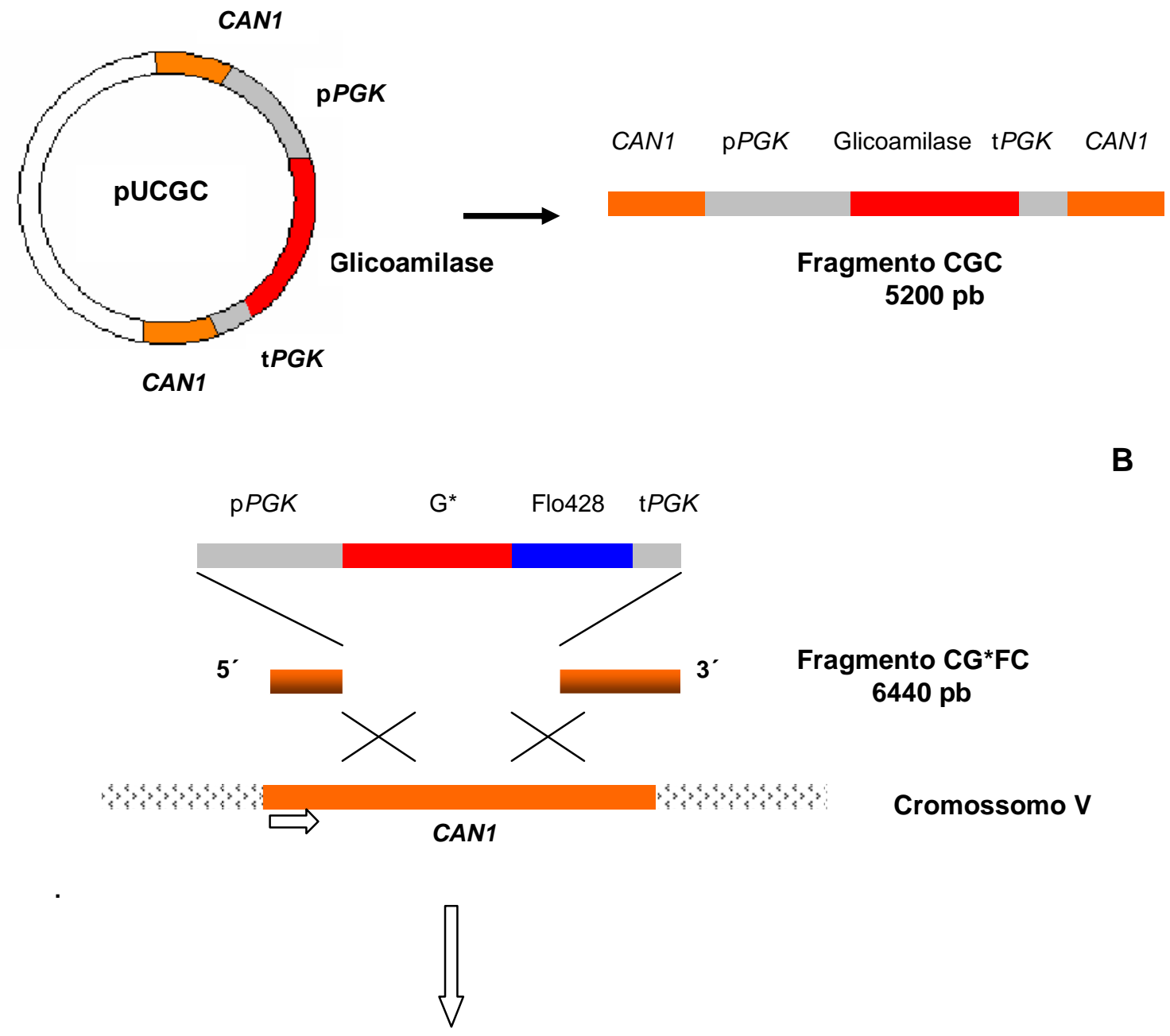

B

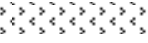

Cromossomo V

Figura 3. Esquema representativo da inserção do fragmento $C G C(A)$ e $C G^{*} F C$ (B) no genoma CAN1 de S. cerevisiae, por recombinação homologa, interrompendo o gene da permease arginina (Modificado de Camargo,2000). 


\subsection{Sistema de ancoragem à superfície celular de levedura "cell surface display"}

A superfície celular é uma interface funcional entre o interior e o exterior da célula. As proteínas da superfície celular são responsáveis pela maior parte das funções da superfície da célula, funcionando como moléculas de adesão entre células, receptores específicos, enzimas e proteína transportadoras. Algumas proteínas superficiais atravessam a membrana plasmática e outras estão ligadas por interações covalentes ou não covalentes aos componentes da superfície celular. As células têm sistemas para ancoragem de proteínas especificas de superfície, e para confinar proteínas superficiais a determinados domínios na superfície celular.

O primeiro sistema de expressão de proteínas heterólogas ancoradas à superfície celular de microrganismos foi desenvolvidos nos anos 80, quando George Smith demonstrou que era possível fusionar peptídeos e proteínas pequenas à proteína plll de fago filamentoso de Escherichia coli (Scott e Smith, 1990). Isto levou ao desenvolvimento de sistemas de ancoragem em fagos "phage-display" (Chiswell e Mccafferty, 1992). Desde então, vários sistemas de ancoragem em fago foram desenvolvidos para expressar proteínas heterólogas na superfície do fago, facilitando o isolamento de ligantes específico, antígenos, e anticorpos de bibliotecas complexas (Hoogenboon, 1997). No entanto, o tamanho da proteína heteróloga ancorada à superfície de fago é um tanto limitado, já que não são incorporados rapidamente nas partículas do fago (Lee, 2000).

A partir de então, surgiram inúmeros sistemas de ancoragem de proteínas heterólogas à superfície celular de bactérias Gram negativas e Gram positivas. Para a expressão e ancoragem da proteína heteróloga na superfície celular, o gene codificador de uma proteína de superfície celular de bactéria foi fusionada com o gene codificador da proteína heteróloga de interesse, desta forma a fusão protéica foi transportada através da membrana celular até a superfície celular da bactéria. 
Em bactérias Gram positivos, a ancoragem de proteínas heteróloga na superfície celular foi alcançada utilizando como âncoras a proteína $A$ de Staphylococcus aureus (Gunneriusson et al.,1996; Samuelson et al., 1995; Schneewind et al., 1995), proteína M6 de Streptococcus pyogenes (Medaglini et al. 1995) e proteína Fibronectina de Streptococcus pyogenes (Hanski et al., 1992) para ligar proteínas heterólogas na superfície celular. Em bactérias Gram negativas, as proteínas da membrana externa (Bae et al., 2000; Little et al., 1993; Georgiou et al., 1993; Georgiou et al., 1997; Francisco et al., 1992; Francisco et al., 1993), lipoproteínas (Harrison et al., 1990), fimbria (Hedegaard e Klemm., 1989) e proteínas flagelares (Newton, et al., 1989) foram utilizadas como âncoras para imobilizar proteínas heterólogas à superfície celular.

O desenvolvimento de sistemas de ancoragem de proteínas heterólogas à superfície celular de microrganismos tem varias aplicações biotecnológicas e industriais como: desenvolvimento de vacinas (Lee et al., 2000; Liljeqvist et al., 1997); produção de anticorpos (Martineau et al., 1991); desenvolvimento de biocatalizadores por imobilização de enzimas (Richins et al., 1997); bioadsorbentes celulares, para remoção de metais pesados e químicos nocivos (Bae et al., 2000; Bae et al., 2002; Sousa et al., 1998; Xu e Lee, 1999); biosensores através da ancoragem de enzimas, receptores ou outros componentes sensíveis a sinais para propósitos ambientais ou industriais (Dhillon et al., 1999; Shibasaki et al., 2001), etc. (Figura 4). 


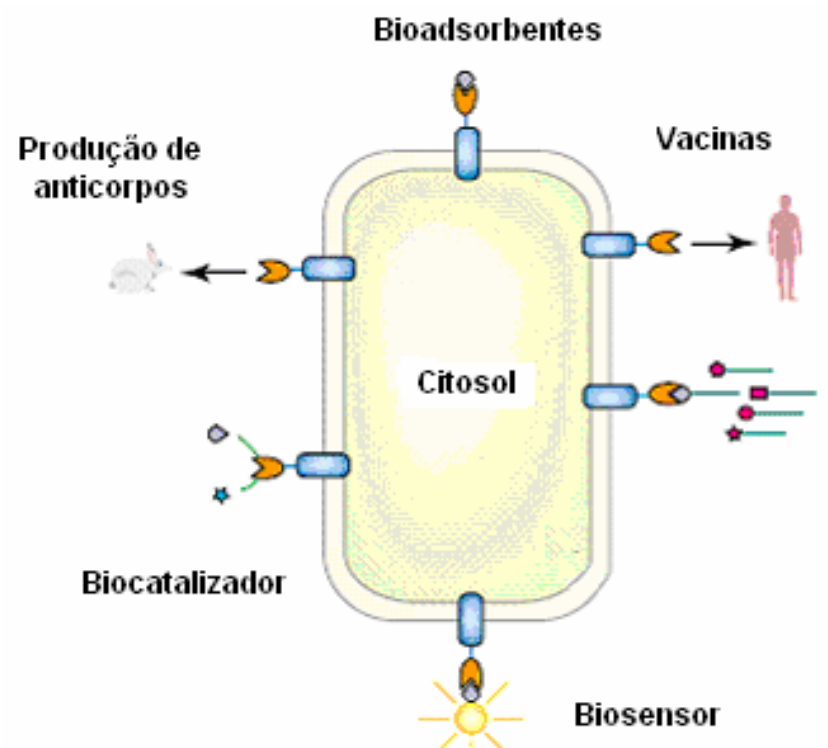

Figura 4. Aplicações do sistema de ancoragem em microrganismos (Lee et al., 2003)

Nos últimos anos foram desenvolvidos vários sistemas que permitiram a construção de linhagens recombinantes que apresentam proteínas heterólogas com atividades catalíticas ancoradas à superfície celular externa da levedura S. cerevisiae, sendo chamadas de "células de leveduras armadas" ("arming yeast cells") (Lee et al., 2003; Kondo e Ueda, 2004; Ueda e Tanaka, 2000a; Ueda e Tanaka, 2000b; Van der Vaart et al., 1997; Schreuder, 1996).

A expressão de proteínas ancoradas à superfície celular de $S$. cerevisiae oferece mais vantagens do que sistemas utilizando outros organismo. Primeiro, S. cerevisiae é um organismo seguro (GRAS) empregado há muitos anos na produção de alimentos e fármacos; segundo, é de fácil manipulação genética, as linhagens utilizadas em laboratório de pesquisa tem sua genetica e fisiologia bem definidas, o que facilita sua aplicação e permite o desenvolvimento de novas técnicas de manipulação genética; e terceiro, a estrutura rígida da célula faz à levedura conveniente para várias das aplicações já mencionadas. Além disso, a levedura pode ser cultivada numa alta densidade em um meio de cultura barato. 
A levedura $S$. cerevisiae possui externamente à membrana plasmática, uma parede celular rígida de aproximadamente de $200 \mathrm{~nm}$ de espessura, que é formada por três componentes principais: glucana, um polímero de $\beta-1,3$ e $\beta-1,6$ glicose (48-60\%), mananaproteínas (20-23\%) e quitina, um polímero de $\beta-1,4 \mathrm{~N}$ acetilglicosamina (0,6-2,7\%) (Fleet, 1985 e Klis, 1994) (Figura 5).

A glucana forma parte da camada interna da parede celular, formando um esqueleto rígido que confere rigidez e flexibilidade à célula. $A \beta-1,3$ glucana forma uma rede fibrosa e tem um tamanho estimado de 1500 resíduos de glicose, enquanto que a $\beta-1,6$ glucana é amplamente ramificada, apresentando de 150 a 200 resíduos de glicose (Manners et. al., 1973 a,b). Segundo Kapteyn et al., 1999, Pololo e Vai, 1999 e Kapteyn et et al., 2000, relataram que as proteínas $\beta-1,6$ glucana, $\beta-1,3$ glucana e quitina da parede celular estão interconectadas por ligações covalentes.

As mananaproteínas são glicoproteínas altamente glicosilados que estão situadas na camada externa da parede celular, conferindo porosidade à parede celular. A parede celular de Saccharomyces sp. contém mais de 20 tipos de mananaproteínas que desempenham papéis diferentes na construção, preservação, modificação da estrutura e interação das células como, por ex., as interações intercelulares durante a aglutinação ou floculação. As mananaproteínas podem ser divididas em três grupos: proteínas unidas por pontes dissulfeto ou ligações não covalentes com polissacarídeos estruturais da parede (a maioria dessas proteínas apresentam atividades enzimáticas e podem ser extraídas por meio de aquecimento com SDS e mercaptoetanol); proteínas ligadas covalentemente principalmente às $\beta$-glucanas e que podem somente ser extraídas pela lise da parede celular com diferentes preparações de glucanases, como zimolyase ou laminarinase (a função fisiológica dessas proteínas não é conhecida), e, proteínas, provavelmente, ligadas de forma covalente à parede celular e que podem ser extraídas com NaOH 30 mM (Mrsa et al., 1999 a, b).

A quitina é um polímero de $\mathrm{N}$-acetilglicosamina com ligações $\beta-1,4$ encontrada em carapaças de insetos, parede celular de fungos e crustáceos. Em leveduras, a quitina é encontrada predominantemente em septos primários e em 
volta do círculo de constrição entre a célula mãe e a jovem. Cerca de $90 \%$ da quitina está localizada na cicatriz de brotamento e o restante, na parede celular.

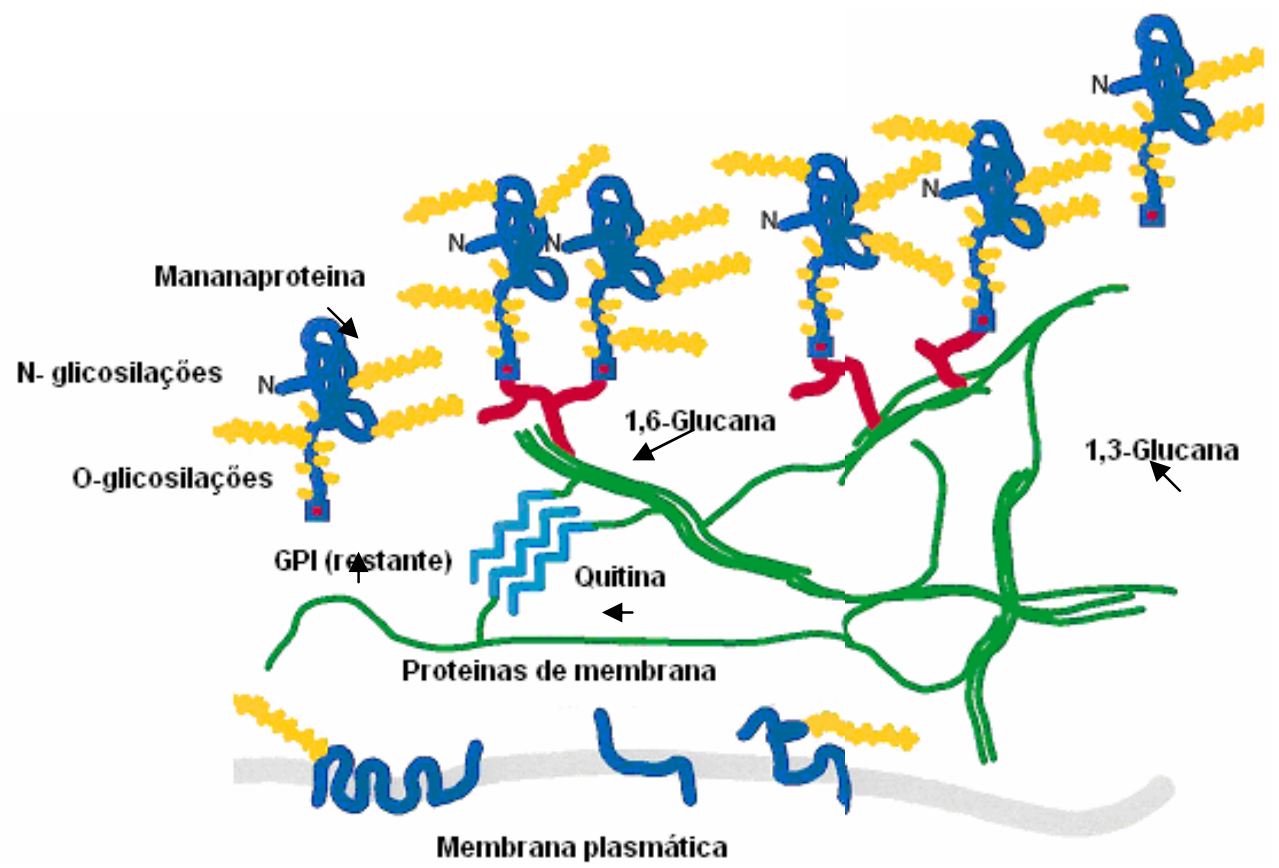

Figura 5. Estrutura da parede celular de S. cerevisiae (Lipke e Ovalle, 1998)

Varias mananaproteínas de S. cerevisiae como: Aga1(aglutinina) (Lipke et al., 1989), Flo1p (Watari et al., 1994), Sed1 (Hardwick et al., 1992), Cwp1, Cwp2 Tip1 Tir1/Srp1 (Van der Vaart et al., 1995) estão covalentemente ligadas a uma estrutura denominada Glicosilfosfatidilinositol (GPI). GPI foi encontrada em várias proteínas de membrana plasmática de eucariotos (Cross 1990; Dustin et al., 1987; Fredette et al., 1993; Homans et al., 1988) e sua estrutura é altamente conservada entre diferentes organismos (Fergunson e Willians, 1998). A estrutura central da GPI de leveduras é semelhante a aquelas encontradas em outros eucariontes (Conzelmann et al., 1988; Lipke et al., 1989; Leidich et al., 1994) e é composta de: etanol-amino fosfato, manose $(\alpha-1,2)$, manose $(\alpha-1,6)$, manose $(\alpha-1,4)$, glicosamine $(\alpha-1,6)$, e inositol-fosfolipídio (Ueda e Tanaka, 2000b) (Figura 6). A parte glicofosofolipidica de GPI é covalentemente ligada à 
região C-terminal das proteínas e sua função principal é permitir uma associação estável da proteína com a membrana plasmática.

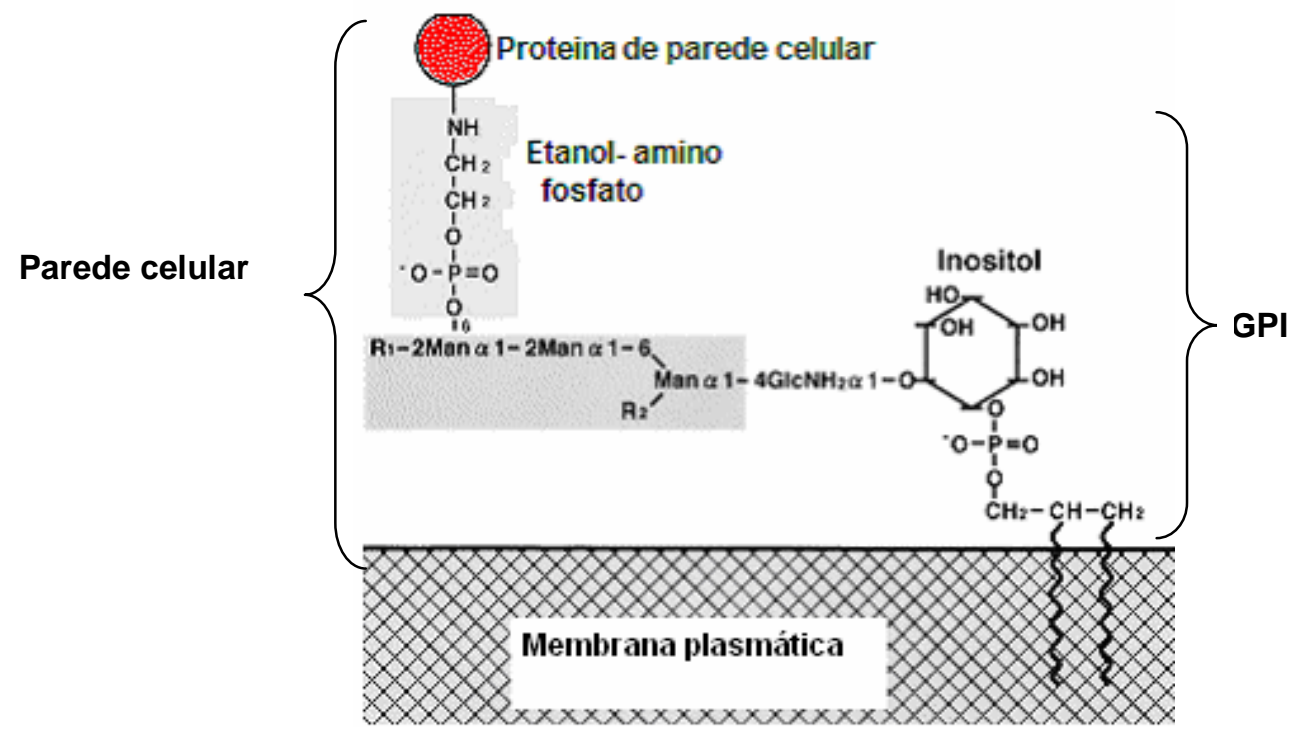

Figura 6. Componentes estruturais de Glicosilfosfatidilinositol (GPI). Man (manose);

Estudos realizados com a proteína de adesão celular $\alpha$-aglutinina permitiu propor uma hipótese do mecanismo de ancoragem das mananaproteínas na parede celular. Desta forma as mananaproteínas que serão unidas a GPI, inicialmente são expressas na forma de um precursor protéico, que permanece ligado na membrana do retículo endoplasmático $(R E)$ por sua seqüência hidrofóbica carboxi-terminal, enquanto que a região amino-terminal permanece no lúmem do RE. Em menos de um minuto, a seqüência carboxi-terminal é clivada por uma transamidase no sítio $\omega$ (cerca de 12 aa do carboxi terminal) e nesta posição é formada uma ligação covalente com a estrutura GPI (Ueda e Tanaka, 2000b). Uma vez que a proteína se liga covalentemente a GPI, esta é direcionada pelo peptídeo sinal através da via secretora até a membrana celular, onde uma porção é clivada pela fosfatidilinositol-fosfolipase (PI-PLC) e o restante da proteína é transferido para a superfície externa da parede celular, 
formando uma ligação com a glicana da parede celular (Kapteyn et al., 1996; Lu et al., 1994,1995) (Figura 7).

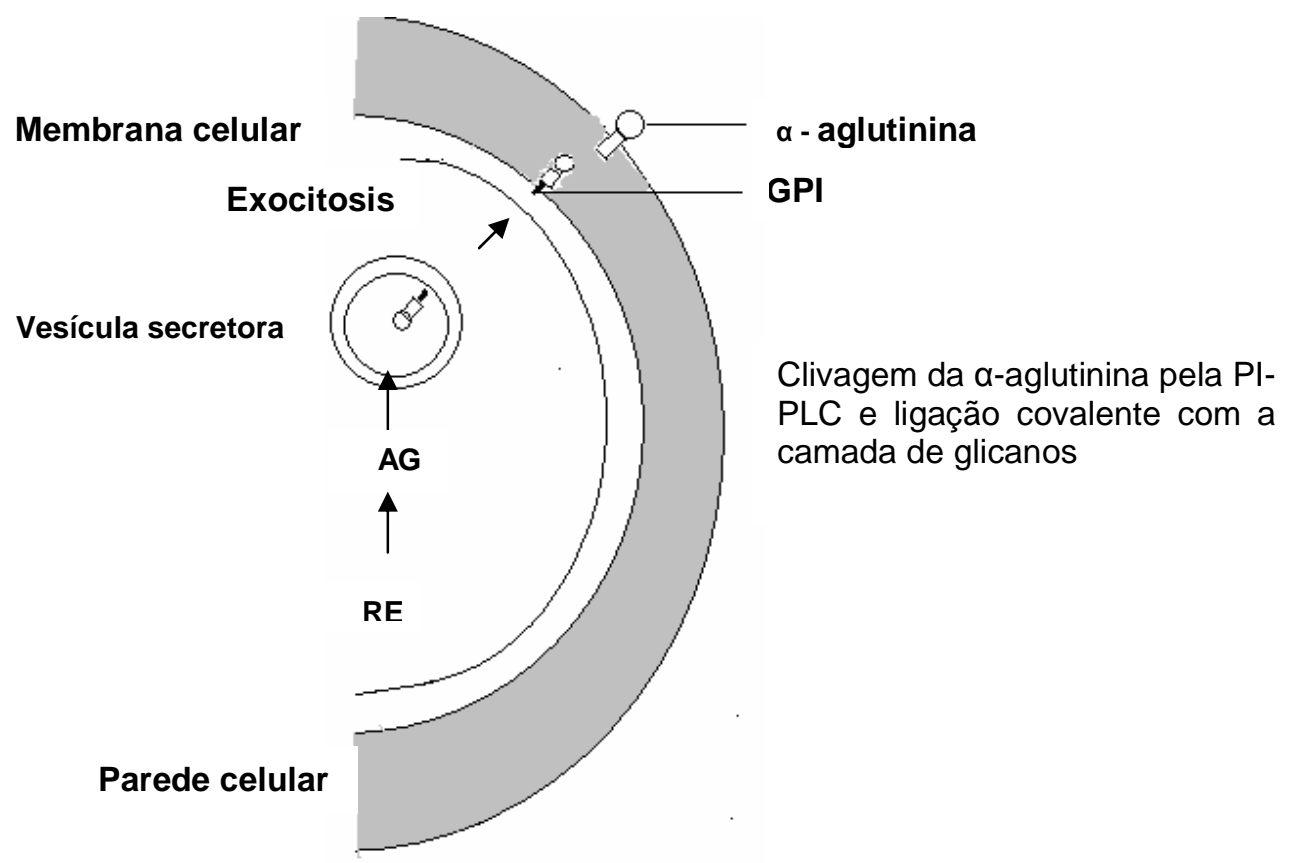

Figura 7. Transporte de mananaproteína à parede celular de levedura, utilizando como modelo à $\alpha$-aglutinina. RE, retículo endoplasmático; AG, aparelho de Golgi PIPLC, fosfatidilinositol - fosfolipase C específica (Ueda e Tanaka, 2000 b).

Nos sistemas descritos, as proteínas heterólogas ancoradas à superfície celular foram fusionadas a um peptídeo sinal, que direciona o transporte da proteína para a superfície celular, e a uma região codificadora do domínio de ancoragem de proteínas nativas de parede celular, como: a-aglutinina, proteína Flo1, proteína Cwp2 de S. cerevisiae (Murai et al., 1997; Nakamura et al., 2001; Van der Vaart et al., 1997) Desta forma, a proteína heteróloga permanece ancorada à superfície celular externa da levedura (Figura 8). 
Seqüência codificadora GPI (Seqüência codificadora do peptídeo sinal do domínio de ligação a GPI)
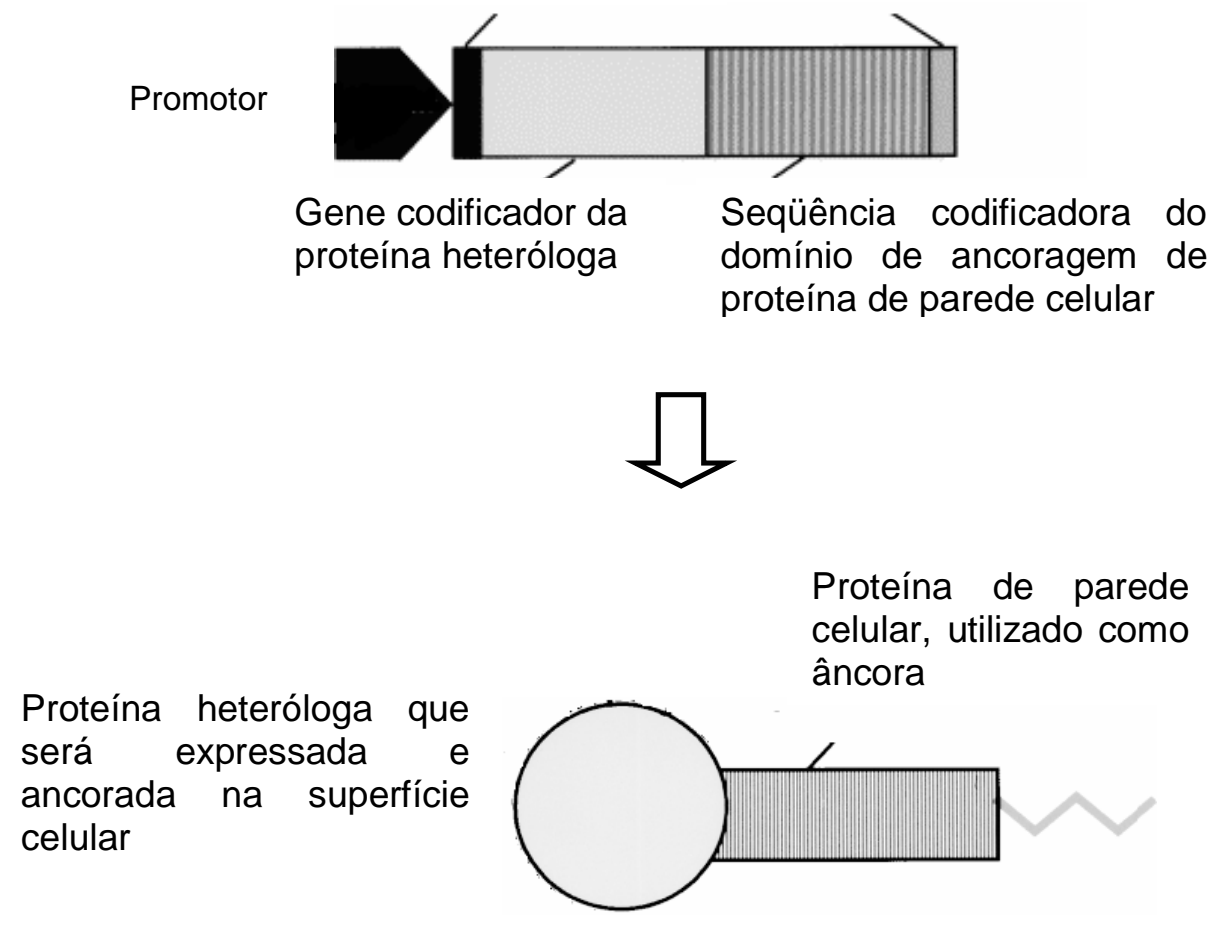

Figura 8. Esquema de construção molecular para expressar proteínas heterólogas ancoradas à superfície celular de levedura $S$. cerevisiae ("cell surface display") (Ueda e Tanaka, 2000 b).

Para avaliar a eficiência do sistema de ancoragem construído neste trabalho foi empregado como gene repórter o c-DNA da glicoamilase de A. awamori, o qual é um marcador direto de seleção para S. cerevisiae que não produz normalmente amilases, alem de ser de grande valor para pesquisas biotecnológicas. Por tanto $S$. cerevisiae não é capaz de converter o amido diretamente, sendo necessárias usualmente duas etapas prévias para a conversão do amido em açúcares fermentescíveis: liquefação ou dextrinização com a enzima $\alpha$-amilase e sacarificação com a glicoamilase (Nakamura, 1996). Segundo Verma et al. (1999) a adição de enzimas ao processo aumenta de forma considerável o custo do processo 
Glicoamilase de $A$. awamori é uma exohidrolase (a1,4-D-glucanglucohidrolase E.C.3.2.1.3.), que catalisa a liberação de resíduos de glicose a partir de extremidades não redutoras de amido e polímeros relacionados (Yamasaki et al., 1977). Por tanto, a ancoragem de glicoamailse na parede celular de $S$. cerevisiae pode facilitar a utilização de amido pela levedura, assimilando a glicose liberada para proliferar e fermentar; sendo este sistema de ancoragem de grande interesse tanto do ponto de vista econômico como tecnológico.

Dentre os sistemas de ancoragem de proteínas heterólogas à superfície celular em S. cerevisiae destaca-se Flop1 (Murai et al., 1997; Sato et al., 2002). Fo1p esta presente na parede celular e responsável pela floculação (Miki et al., 1982; Teunissen et al.,1993). Este fenômeno consiste na agregação das células de levedura em flocos e sua subseqüente remoção do meio de fermentação por sedimentação.

O gene FLO1 de $S$. cerevisiae codifica a proteína Flo1p, rica em serina e treonina, composta por 1536 aminoácidos, Devido ao número elevado de possíveis sítios de $O$ e $\mathrm{N}$-glicosilação, a proteína adota uma conformação estendida, rígida, tipo bastão, atravessando a parede celular e expondo a região N-terminal na superfície celular (Watari et al., 1994), permitindo desenhar âncoras de diferentes tamanhos da região C-terminal de Flo1p. Esta proteína é composta por vários domínios: seqüência sinal de excreção (presente na região amino terminal); domínio funcional da floculação (que se repete por 18 vezes); domínio de ancoragem a membrana; e, sinal de ligação a glicofosfatidilinositol (GPI - presente na região carboxi terminal), através da qual a proteína Flo1p é ligada à superfície celular (Miki et al., 1982; Teunissen et al.,1993; Watari et al., 1994) (Figura 8). 


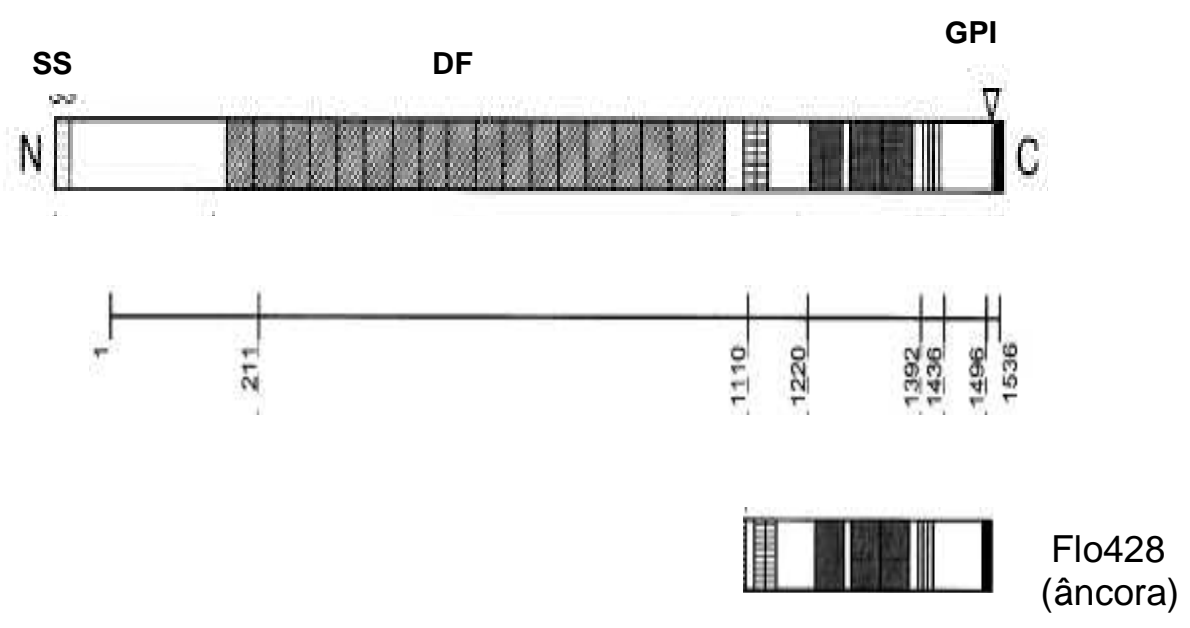

Figura 9. Esquema da proteína Flo1p. SS, seqüência sinal; DF, domínio de seqüência de ligação GPI (Sato et al., 2002)

Em trabalhos anteriores foi demonstrado, claramente, que o tamanho da âncora influência na exposição da enzima ancorada à superfície celular da célula de levedura. Assim, o tamanho da âncora interfere em sua ação sobre o substrato, uma vez que para sua maximização da exposição ao meio, toda a espessura da parede celular precisa ser atravessada pela proteína âncora (Sato et al., 2002)

Com base nessa informação, neste trabalho foi utilizado como âncora um fragmento de 428 aminoácidos da região C-terminal da proteína de parede celular Flo1p, que doravante foi denominado de Flo428, para imobilizar a enzima glicoamilase de $A$. awamori na superfície celular externa de S. cerevisiae (Figura 8). O c-DNA da glicoamilase utilizado continha a seqüência codificadora do peptídeo sinal que direciona o transporte da enzima través da membrana plasmática para ser localizado na parede celular da levedura. 


\section{CONCLUSÕES}

- O sistema de ancoragem desenvolvido permite a expressão e imobilização da enzima glicoamilase de Aspergillus awamori na superfície celular de Saccharomyces cerevisiae.

- O cassete de ancoragem ladeado por fragmentos do gene CAN1 permite introduzir no genoma da levedura a informação desejada e possibilita a seleção direta, através da resistência a L-canavanina, das células recombinantes.

- $\quad$ fragmento de ancoragem $C^{*} G^{*} C$ utilizado na transformação gênica de leveduras permitiu a fácil detecção dos clones recombinantes de levedura, através da produção de halos de amilolise após crescimento em YPDA, tornando-as capazes de degradar amido do meio de cultura.

- A linhagem de levedura recombinante obtida por transformação genética com o sistema $\mathrm{CG}^{*} \mathrm{FC}$, apresentou um pequeno aumento da capacidade de expressão de glicoamilase em relação à capacidade da mesma linhagem transformada com o sistema CGC (cujos clones recombinantes excretam glicoamilase para o meio de cultura) e também, em relação à linhagem original não transformada.

- Este sistema oferece a possibilidade de ancorar na superfície celular da levedura, enzimas ativas e proteínas funcionais, dotando às células com novas propriedades benéficas e aumentando o "status" de $S$. cerevisiae como um organismo atrativo capaz de atuar como biocatalizador celular.

- Uma vantagem do sistema construído é a recuperação e re-utilização das células que podem ser utilizadas como fonte de proteínas imobilizadas nos processos biotecnológicos. 


\section{REFERÊNCIAS BIBLIOGRÁFICAS*}

Ausubel FM, Brent R, Kingston RE, Moore DD, Seidman JG, Strurhl RE. In: Current Protocols in Molecular Biology. New York: John Wiley e Sons; 1989.

Bae W, Chen W, Mulchandani A, Mehra RK. Enhanced bioaccumulation of heavy metals by bacterial cells displaying synthetic phytochelatins. Biotechnol Bioengineer. 2000;70:518-524.

Bae W, Mulchandani A, Chen W. Cell surface display of synthetic phytochelatins using ice ucleation protein for enhanced heavy metal bioaccumulation. J Inorg Biochem. 2002;88:223-227.

Becker DD, Guarante L. High-efficiency transformation of yeast by electroporation. In: Guide to yeast genetics and molecular biology. Inc. San Diego: Academic Press; 1991. p.182-87,.

Beggs J.D. Transformation of yeast by a replication hybrid plasmid. Nature. 1978;275:104-108.

Broach JR, Strathern JN, Hicks JB. Transformation in yeast: development of a hybrid cloning vector and isolation of the CAN1 gene. Gene.1979;8:121-133.

Camargo, ME. Construção de um vetor para transformar levedura através da disrupção do gene can1 [Dissertação (Mestrado em Microbiologia)]. São Paulo: Instituto de Ciências Biomédicas da Universidade de São Paulo; 1994.

Camargo, ME. Sistema para transformação de leveduras industriais e detecção de atividade recombinogênica [Tese (Doutoramento em Microbiologia)]. São Paulo: Instituto de Ciências Biomédicas da Universidade de São Paulo; 2000.

\footnotetext{
* De acordo com : INTERNATIONAL COMMITTEE OF MEDICAL JOURNAL EDITORS. Uniform requirements for manuscripts submitted to biomedical journals. Available from:

http://www.nlm.nih.gov/bsd/uniform_requirements.html [2004 May 06].
} 
Chiswell DJ, Mccafferty J. Phage antibodies: will new policlonal antibodies replace monoclonal antibodies?. Trends Biotechnol. 1992;10:80-84.

Conzelmann A, Fankhauser C, Desponds C. Myoinositol gets incorporated into numerous membrane glycoproteins of Saccharomyces cervisiae; incorporation is dependent on phosphomannomutase (SEC53). EMBO J. 1988;9:653-61.

Cross GAM. Cellular and genetic aspects of antigenic variation in trypanosomes. Annu Rev Immunol. 1990;8:83-110.

Dhillon JK, Drew PD, Porter AJ. Bacterial surface display of an anti-pollutant antibody fragment. Lett Appl Microbiol. 1999;28:350-54.

Dustin ML, Selvaraj P, Mattaliano RJ, Springer TA. Anchoring mechanisms for LFA-3 cell adhesion glycoprotein at membrane surface. Nature. 1987:329:84648.

Ferguson MAJ, Williams AF. Cell-surface anchoring of proteins via glycosylphosphatidylinositol structures. Annu Rev Biochem. 1988; 57:285-320.

Fleet GH. Composition and structure of yeast cell walls. Curr Top Med Mycol. 1985;1:24-56.

Francisco JA, Earhart CF, Georgiou G. Transport and anchoring of b-lactamase to the external surface of Escherichia coli. Proc Natl Acad Sci USA. 1992;9:271317.

Francisco JA, Stathopoulos C, Warren R.A.J, Kilburn DG, Georgiou G. Specific adhesion and hydrolysis of cellulose by intact Escherichia coli expressing surface anchored cellulase or cellulose binding domains. Bio/Technology. 1993;11:49195.

Fredette B, Rutishauer U, Landmesser L. Regulation and activity-dependence of $\mathrm{N}$-cadherin, NCAM isoforms, and polysialic acid on chick myotubes during development. J Cell Biol, 1993;123:1867-88. 
Georgiou G, Poetschke HL, Stathopoulos C, Francisco JA. Practical applications of engineering gram-negative bacterial cell surfaces. Trends Biotechnol. 1993;11:6-10.

Georgiou G, Stathopoulos C, Daugherty PS, Nayak AR, Iverson BL, Curtiss R. Display of heterologous proteins on the surface of microorganisms: from the screening of combinatorial libraries to live recombinant vaccines. Nat Biotechnol. 1997;15:29-34.

Gouffeau A, Barrell BG, Bussey H, Da Vis RW, Dujon B, Feldmann H, Gaubert F, Hoheisel JD, Jacq C, Jonston M, Louis E, Mewes HW, Murakami Y, Philippsen P, Tettelin H, Ouver SG. Life with 6000 genes. Science. 1996;274:546, 563-67.

Guerra OG. Construção de um plasmidio bifuncional contendo um sistema indutor de retrotransposição para Saccharomyces cerevisiae [disertação (Mestrado em Microbiologia)]. São Paulo: Instituto de Ciências Biomédicas da Universidade de São Paulo; 2002.

Hadfield C, Raina KK, Shashi-Menon K, Mount RC. The expression and performance of cloned genes in yeasts. Micol Res. 1993;97:897-944.

Hammond JRM. Brewer'S Yeast. In: The yeast. 2 ed. New York. Academic Press; 1993. V.5. Cap. 2.

Hanski E, Horwitz PA, Caparon, MG. Expression of protein F, the fibronectinbinding protein of Streptococcus pyogenes JRS4, in heterologous streptococcal and enterococcal strains promotes their adherence to respiratory epithelial cells. Infect Immun. 1992. 60(12):5119-25

Hardwick KG, Boothroyd JC, Rudner AD, Pelham R.B. Genes that allow yeast cells to grow in the absence of the HDEL receptor. J EMBO. 1992;11:4187-95.

Harrison JL, Taylor IM, O'Connor CD. Presentation of foreign antigenic determinants at the bacterial cell surface using the TraT lipoprotein. Res Microbiol. 1990;141:1009-12. 
Hauff J, Zimmermann FK, MullerS. Simultaneous genomic overexpresssion of seven glicolytic enzymes in the yeast Saccharomyces cerevisiae. Enzym Microbial Technol. 2000;26:688-98.

Hedegaard L, Klemm P. Type 1 fimbriae of Escherichia coli as carrier of heterologous antigenic sequences. Gene. 1989;85:115-24.

Hinnen A, Hick JB, Fink GR. Transformation of yeast. USA, Proc Natl Acad Sci. 1978;75:1929-33.

Hitzeman RA, Hagie FE, Levine HL, Goedel DV, Ammerer G, Hall BD. Expression of a human gene for interferon in yeast. Nature. 1981;293:717-22.

Homans SW, Ferguson MA, Dwek RA, Rademacher TW, Anand R, Williams AF. Complete structure of the glycosyl phosphatidylinositol membrane anchor of rat brain Thy-1 glycoprotein. Nature. 1988;333:269-72.

Hoogenboom HR. Designing and optimizing library selection strategies for generating high-affinity antibodies. Trends Biotechnol. 1997;15:62-70,.

Ito $\mathrm{H}$, Fukuda $\mathrm{Y}$, Murata $\mathrm{K}$, Kimura $\mathrm{A}$. Transformation of intacts yeast cells treated with alkali cations. J Bacteriol. 1983;153:163-68.

Johnston SA, Anziano PQ, Shark K, Sanford JC, Butow RA. Mitochondrial transformation in yeast by bombardment with microprojectiles. Science, v 240, p. 1538-1541, 1988.

Kapteyn JC, Montijn RC, Vink E, De La Crua J, Llobell A, Douwes JE, Shimoi H, Lipke PN, Klis FM. Retention of Saccharomyces cerevisiae cell wall proteins through a phosphodiester-linked b-1,3-/b-1,6-glucan heteropolymer. Glycobiology. 1996;6:337-45.

Kapteyn JC, Van Egmond P, Sievi E, Van Den Ende H, Makarow M, Klis FM. The contribution of the O-glycosylated protein Pir2p/Hsp150 to the construction of the yeast cell wall in wild-type cells and beta 1,6-glucan-deficient mutants. Mol Microbiol. 1999;31:1835-44. 
Kapteyn JC. The cell wall architecture of Candida albicans wild-type cells and cell wall-defective mutants. Mol Microbiol. 2000;35:601-11.

Kim MD, Rhee SK, Seo JH. Enhaced production of anticoagulant hirudin in recombinant Saccharomyces cerevisiae by chromosomal delta-integratiion. J Biotechnol. 2001;85:41-48.

Kingsman AJ, Kingsman SM. The production of mammalian proteins in Saccharomyces cerevisiae. Tibtech. 1987;5:53-57.

Klis FM. Cell wall assembly in yeast. Yeast. 1994;10:851-69.

Kondo A, Ueda, M. Yeast cell surface display - application of molecular display. Appl Microbiol Biotechnol. 2004;64:28-40.

Kukuruzinska, MA, Bergh MLE, Jackson BJ. Protein glycosylation in yeast. Ann Rev Biochem. 1987;56:915-44.

Lee J-S, Shin K-S, Pan J-G, Kim C-J. Surface-displayed viral antigens on salmonella carrier vaccine. Nat. Biotechnol. 2000;18: 645-48.

Lee SY, Choi JH, Xu Z. Microbial cell-surface display. Trends Biotechnol. 2003;21(1):45-51.

Leidich SD, Drapp DA, Orlean P. A conditionally lethal yeast mutant blocked at the first step in glycosyl phosphatidylinositol anchor synthesis. J Biol Chem. 1994; 369:10193-96.

Liljeqvist S, Samuelson P, Hansson M, Nguyen TN, Binz H, Stahl S. Surface display of the cholera toxin $B$ subunit on Staphylococcus xylosus and Staphylococcus carnosus. Appl Environ Microbiol. 1997;63:2481-88.

Lipke PN, Wojciechowicz D, Kurjan J. AGa1 is the structural gene for the Saccharomyces cerevisiae a-agglutinin, a cell surface glycoprotein involved in cell-cell interactions during mating. Mol Cell Biol. 1989;9:3155-65. 
Lipke PN, Ovalle R. Cell Wall Architecture in Yeast: New Structure and New Challenges. J Bacteriol. 1998;180:3735-3740.

Little M, Fuchs P, Breitling F, Dubel S. Bacterial surface presentation of proteins and peptides: an alternative to phage technology? Trends Biotechnol. 1993;11: 3-5.

Lu C, Kurjan J, Lipke PN. A pathway for cell anchorage of Saccharomyces cerevisiae a-agglutinin. Mol Cell Biol. 1994;14:4825-33.

Lu CF, Montijin RC, Brown JL, Klis FM, Kurjan J, Bussey H, Lipke PN. Glycosylphosphatidylinositol-dependent cross-linking of a-agglutinin and $\beta 1,6$ glucan in the Saccharomyces cerevisiae cell wall. J Cell Biol. 1995;128:333-40.

Manners DJ, Masson AJ, Patterson C. The structure of a B-(1-3)-d-glucan from yeast cell walls. J Biochem. 1973a;135:19-30.

Manners DJ, Masson AJ, Patterson C. The structure of a B-(1-6)-d-glucan from yeast cell walls. J Biochem. 1973b;135:19-30.

Martineau P. A genetic system to elicit and monitor antipeptide antibodies without peptide synthesis. Bio/Technology. 1991;9:170-72.

Medaglini D, Pozzi G, King TP, Fischetti VA. Mucosal and systemic immune responses to a recombinant protein expressed on the surface of the oral commensal bacterium Streptococcus gordonii after oral colonization. Proc Natl Acad Sci USA. 1995; 92(15): 6868-72.

Meilhoc E, Masson JM,Tessie J. High efficiency transformation of intact yeast cells by electroporation. Bio Technol. 1990;8:223-37.

Mellor J, Dobson MJ, Roberts NA, Tuite MF, Emtage JS, White S, Lowe PA, Patel T, Kingsman AJ, Kigsmans SM. Efficient synthesis of enzymatically active calf chymosin in Saccharomyces cerevisiae. Gene. 198;24:1-14. 
Miki BL, Poon NH, James AP, Seligy VL. Possible mechanism for flocculation interactions governed by gene FLO1 in Saccharomyces cerevisiae. J Bacteriol. 1982;150:878-89.

Miyamoto C, Chizzonite R, Crowl R, Rupprecht K, Kramer R, Schaber M, Kumar G, Poonian M, Ju G. Molecular cloning and regulated expression of the human cmyc gene in Escherichia and Saccharomyces: comparison of the products. Proc Natl Acad Sci USA. 1985;82:7732-36.

Mrsa V, Seidl T, Gentzsch M, Tanner W. Specific labelling of cell wall proteins by biotinylation. Identification of four covalently linked O-mannosylated proteins of Saccharomyces cerevisiae. Yeast. 1997;13:1145-54.

Murai T, Ueda M, Yamamura M, Atomi H, Shibasaki Y, Kamasawa N, Osumi M, Amachi T, Tanaka A. Construction of a starch-utilizing yeast by cell surface engineering. Appl Environ Microbiol. 1997;63:1362-66.

Nakamura Y, Shibasaki S, Ueda M, Tanaka A, Fukuda H, Kondo A. Development of novel whole-cell immunoadsorbents by yeast surface display of the IgG-binding domain. Appl Microbiol Biotechnol. 2001;57:500-05.

Newton SMC, Jacob CO, Stocker BAD. Immune response to cholera toxin epitope inserted in Salmonella flagellin. Science. 1989;244(4900):70-72.

Oekarová M, Caspari T, Pinson B, Bréthes D, Tanner W. Post-translational fate of can1 permease of Saccharomyces cerevisiae. Yeast. 1998;14:215-24.

Popolo LE, Vai M. The gas1 glycoprotein, a putative wall polymer cross-linker. BBB-Gen. 1999;1426(2):385-400.

Pozzi GMR, Oggioni R, Manganelli R, Medaglini D, Fischetti VA, Fenoglio D, Valle MT, Kunkl A, Manca F. Human T-helper cell recognition of an immunodominant epitope of HIV-1 gp120 expressed on the surface of Streptococcus gordonii. Vaccine. 1994;12(12):1071-77.

Romanos MA, Scorer CA, Clare JJ. Foreign gene expression in yeast: A Review. Yeast. 1992;8:423-88. 
Rothstein RJ. One step gene disruption in yeast. Methodos Enzymol. 1983;101:202-11.

Rubio IGS. Novos vetores de rDNA - transformação e co-transformação de Saccharmoyces cerevisiae, levedura isolada de industrias e da biodiversidade amazônica [tese (Doutorado em Microbiologia)]. São Paulo: Instituto de Ciências Biomédicas da Universidade de São Paulo; 2001.

Sambrook, J, Russell, DW. Molecular Cloning: A laboratory manual. Cold Spring Harbor Laboratory Press, NY; 2001.

Samuelson P, Hansson M, Ahborg N, Andreoni C, Gotz F, Bachi T, Nguyen TN, Binz H, Uhlen M, Stahl S. Cell surface display of recombinant proteins on Staphylococcus carnosus. J Bacteriol. 1995;177:1470-76.

Sato N, Matsumoto T, Ueda M, Tanaka A, Fukuda H, Kondo A. Long anchor using Flo1 protein enhances reactivity of cell surface-displayed glucoamylase to polymer substrates. Appl Microbiol Biotechnol. 2002;60:469-74.

Schneewind O, Fowler A, Faull KF. Structure of the cell wall anchor of surface proteins in Staphylococcus aureus. Science. 1995;269:103-06.

Schreuder MP, Mooren AT, Toschka HY, Verrips CT, Klis FM. Immobilizing proteins on the surface of yeast cells. Trends Biotechnol. 1996;14:115-20.

Scorpione RC, Soares De Camargo S, Schenberg GAC, Astolfi-Filho S. A new promoter - probe vector for Saccharomyces cerevisiae using fungal glucoamilase cDNA as the reporter gene. Yeast. 1993;9:599-605.

Scott JK, Smith, GP. Searching for peptide ligants with an epitope library. Science. 1990;249:386-90.

Sherman F, Fink, GR, Lawrence CW. Methods in yeast genetics: laboratory manual. New York: Cold Spring harbor; 1979. Cold Spring Laboratory.

Schreuder MP, Mooren AT, Toschka HY, Verrips CT, Klis FM. Immobilizing proteins on the surface of yeast cells. Trends Biotechnol. 1996;14:115-20. 
Shibasaki S, Ueda M, Ye K, Shimizu K, Kamasawa N, Osumi M, Tanaka A. Creation of cell surface-engineered yeast that display different fluorescent proteins in response to the glucose concentration. Appl Microbiol Biotechnol. 2001;57:528-33.

Sousa C, Kotrba P, Ruml T, Cebolla A, De Lorenzo V. Metalloadsorption by Escherichia coli cells displaying yeast and mammalian metallothioneins anchored to the outer membrane protein LamB. J Bacteriol. 1998;180:2280-84,.

Sprague, GF. Mating and mating-type interconversion in Saccharomyces cerevisiae and Saccharomyces pombe. In: The Yeasts 2 ed. London. Academic Press; 1995.v.6,cap 11.

Teunissen AW, Holub E, Van Der Hucht J, Van Den Berg JÁ, Steensma HY. Sequence of the open reading frame of the FLO1 gene from Saccharomyces cerevisiae. Yeast. 1993;9:423-27.

Towler DA, Gordon JI, Adams SP, Glaser L. The biology and enzymology of eukaryotic acylation. Ann Rev Biochem. 1988;57:69-99.

Ueda M, Tanaka A. Cell surface engineering of yeast- construction of arming yeast with biocatalyst . J Biosci Bioeng. 2000a;90:125-36.

Ueda, M, Tanaka A. Genetic immobilization of protein on the yeast cell surface. Biotechnol Adv. 2000b;18:121-40

Valenzuela P, Medina A, Rutter WJ, Ammerer G, Hall BD. Synthesis and assembly of hepatitis B surface antigen particles. Nature. 1982; 298:347-50.

Van Der Vaart JM, Chapman JW, Kliss FM, Verrips CT. Identication of three mannoproteins in the cell wall of Saccharomyces cerevisiae. J Bacteriol. 1995;177:3104-10.

Van Der Vaart J.M, Biesebeke R, Chapman JW, Toschka HY, Klis FM, Verrips CT. Comparison of cell wall proteins of Saccharomyces cerevisiae as anchor for cell surface expression of heterologous proteins. Appl Environ Microbiol. 1997;63:615-20. 
Verma G, NiganP, Singh D, Chaudhary K. Bioconversion of starch to ethanol in a single-step process by coculture of amylolytic yeast and Saccharomyces cerevisiae 21. Bioresource Technology. 2000;72:261-66.

Walker GM. Yeast Phisiology and Biotechnology. New York: John Wiley \& Sons; 1998.

Watari J,Ttakata $\mathrm{Y}$, Ogawa M, Sahara H, Koshino M, Onnela ML, Airaksinen U, Jaatinen R, Penttila M, Keranen S. Molecular cloning and analysis of the yeast flocculation gene flo1. Yeast. 1994;10:211-25.

Welhan WL, Gocke E, Manney TR. The can1 locus of Saccharomyces cerevisiae: fine estructure analysis and forward mutation rates. Genetics. 1979;91:35-38.

Wery J, Verdoes JC, Van goyen AJJ. Genetics of non-saccharomyces industrial. in: demain al, davies jl, editors. manual of industrial microbiology. Washington: Asm Press; 1999. p. 447-459.

$\mathrm{Xu}$ Z, Lee SY. Display of polyhistidine peptides on the Escherichia coli cell surface by using outer membrane protein $\mathrm{C}$ as an anchoring motif. Appl Environ Microbiol. 1999;65:5142-47.

Yamasaki Y, Suzuki Y, Osawa J. Three forms of a gllucosidase and glucoamylase from Aspergillus awamori. Agri Biol Chem. 1977;41:2149-61. 